Paul Wexler

Tel-Aviv University

\title{
Why There May Have Been Contacts between Slovenes and Jews before 1000 A.D.
}

\begin{abstract}
V okviru nove teorije o preseljevanju Židov v Evropo avtor trdi, da je najbolje gledati na jidiš kot na narečje lužiške srbščine, ki je bilo naposled preleksikalizirano s srednjevisokonemškim besedjem. Do tega preseljevanja na dvojezična lužiškosrbsko-nemško govoreča ozemlja, ki se je dogajalo do poznega prvega tisočletja, so se Židje selili prek Balkana, kjer so prevzeli enega ali več balkanskih jezikov: romanskega, grškega in/ali južnoslovanskega. Prispevek predstavlja dokaze v prid tej teoriji, s poudarkom na tistih, ki izhajajo s slovenskega ozemlja.

In the framework of an innovative theory on the migration of the Jews to Europe, the origin of Yiddish is viewed as the result of relexification of a dialect of Sorbian to Middle High German vocabulary. Prior to their arrival in Sorbo-German speech territory by the late first millennium A.D., Jews migrated through the Balkans and shifted to one or more Balkan languages: Romance, Greek and/or South Slavic. The present paper presents evidence in support of this theory with an emphasis on evidence from the Slovene territory.
\end{abstract}

Slovenia has never had a significant Jewish population, nor archaeological remains that attest to a Jewish presence in the pre-Slavic period, such as in Croatia, Serbia, Macedonia or Bulgaria; see, e.g., the synagogue at Štip (Stobi), Macedonia from the 3rd-4th centuries or the mixed Avar-Jewish necropolis at Čelarevo in the Vojvodina, thought to date from the 6 th to 8 th centuries. ${ }^{1}$ Detoni claimed that Jews had settled in the vicinity of Maribor during the Roman period, but she gives no archaeological or historical evidence (1957-8: 72). In fact, her assertion that Jews appeared again in the Slovene lands in the 9th-10th century is also conjecture (ibid.).

The first documented evidence of a Jewish presence in Slovenia dates from the 13th century, when Yiddish- and Italian-speaking Jews migrated south from Austria to Maribor and Celje, and east from Italy into Ljubljana. This is a good three centuries after the first mention of Jews in the Austrian lands. Valuable data on the Jewish presence in Slovenia comes from Johann Weichard Valvasor's compendious history of Carniola that appeared in 1689. Here we are told about the construction of a new synagogue in 1213 in Ljubljana (3: 1689: 710 - which implies the presence of a Jewish community perhaps in the 1100s), a document signed by Jews from Maribor, Radkersburg, Judenburg, St. Veit an der Glan and Ljubljana at the close of the 13th century (ibid., 4: 309-10), the claims that Jews poisoned wells in Ljubljana in 1337 (ibid., 4: 319), and that in 1496 they ridiculed the Christian sacraments and killed many Christian children for their blood, which was needed for the production of matzah (unleavened bread eaten at Passover) (ibid., 4: 393).

${ }^{1}$ On Čelarevo, and other cites, see Nedomački 1988a; for a detailed discussion of Čelarevo, see Bunardžić 1980 and Wexler 1993: 30, 193-95. Kollautz and Miyakawa 1970: II note that both Jews and Avars deposited objects in the grave of the deceased. 
Perhaps the most illustrious Jew to have resided in Slovene territory was the Ashkenazic (Yiddish-speaking) rabbi Israel ben Ptaxya Isserlein (Iserlin), who was born in Regensburg in 1390; he was educated in Wiener-Neustadt, arriving in Maribor in 1427, where he apparently resided until 1445 . He was the author of an important Jewish legal treatise in Hebrew, known as Trumat hadešen (Venice 1519), and died in $1460 .{ }^{2}$

Jewish settlement in Slovenia was interrupted when the Jews were expelled from Styria and Carniola in 1496 and from Ljubljana in $1515 .^{3}$ Many of the expelled Jews migrated to Triest, Vienna and Sopron. ${ }^{4}$ The Italian Jewish family name Morpurgo may come from Marburg, the German name for Maribor. Alternatively, the Jewish family name could be derived from the German city of Marburg in Hesse, which also had a Jewish settlement in the 14th century. The fact is that a number of Ashkenazic Jews in Italy named themselves after the German towns and areas from which they originally hailed; see, e.g. Luzzatto < German Lausitz (Ober- and Niederlausitz are the two districts in southeast Germany in which a small Sorbianspeaking population still resides). While large groups of Iberian Jews entered the South Slavic lands and the Ottoman Empire after 1492 (the year of their expulsion from the Kingdom of Spain), the bulk of these settlements were established in Albania, Bosnia, Bulgaria, Macedonia, Greece, and Turkey, and later on in Serbia and Croatia; Slovenia never attracted a significant Judeo-Spanish-speaking population.

Despite the lack of material evidence of an early Jewish presence in Slovene lands, I believe that it is possible to propose, cautiously, the innovative thesis that there were Jews in this area of the Balkans during the first millennium. Contacts between Jews and Slovenes at this time must be established almost exclusively by linguistic evidence (primarily by the facts of Yiddish, and secondarily by the Slavic languages in contact with the latter and possibly other Jewish languages). I theorize that the Balkan Jews of the first millennium consisted of a minority ethnic Palestinian component and a majority population from Europe and Asia Minor which had become either receptive to Jewish culture or who had actively converted to Judaism. In my view, it is among Balkan Jews who migrated north into the mixed Germano-Sorbian lands (of present-day eastern Germany) that the Ashkenazic (North European) Jewish community developed by the latest in the 9th-10th centuries.

\footnotetext{
${ }^{2}$ See Wenninger 1995a: 836. For a list of names of Jews recorded in Maribor from 1350 on, see ibid., 835-7. For a description (with photographic illustrations) of seals belonging to Slovene Jews in the 14th-15th centuries, see Friedenberg 1987: 297-302. Some of the names of Jews as recorded on their seals and in contemporaneous Christian documents differ from Ashkenazic names known from monolingual German lands, see, e.g. Maul (Maribor 1482, possibly a contraction of Hebrew Šmu'el 'Samuel'?). On Slovene Jewish names, see also the discussion below.

Iserlin's Yiddish was the subject of study by Lunski 1924 and Weinreich 1924. Iserlin's writings include the term pjnkw"š - pjnkw"s 'Christian Pentecost', which may be of Hungarian or Slovene origin (though ultimately from German, see my 1987: 33-4), e.g., Hungarian pünkösd, Slovene binkošti. Iserlin's spelling with " indicates that the term was regarded as a foreignism i.e. non-Germanism and non-Hebraism.

${ }^{3}$ For details of Jewish settlement in Celje, Judenburg, Maribor, Radkersburg and St. Veit an der Glan, see Tykocinski 1934, Detoni 1957-8, Lazarus 1968, Nedomački 1988b, Nedomački and Goldstein 1988 and Wenninger 1987a, b, c, 1995a, b, c. Further bibliography on Ashkenazic Jewish history in Slovene territory is cited by Detoni 1957-8 and Wenninger 1987c: 698-702 and 1995a.

${ }^{4}$ See Detoni 1957-8: 74.
} 
The evidence of contact between the Slovenes or a non-Slavic population inhabiting the historic Slovene lands and the Jews in the late first millennium is scant. The failure of historians to pose the possibility of such historic contacts has resulted in insufficient exploitation of the few known facts, as well as a reluctance to seek out new evidence. Hopefully, more research will permit greater precision of formulation and corroboration. Moreover, when set within the broader framework of the Balkans as a whole - where somewhat more historical, archaeological and linguistic evidence is available - an early Slovene-Jewish connection is not implausible. Detailed evidence of a Balkan substratum (Balkan Latin, Greek, and Slavic) in Yiddish was presented in Wexler 1992.

The traditional view of Yiddish genesis is that French and Italian Jews migrated to the Rhineland and secondarily to Bavaria in the 9th century; instead of adopting the local German dialects, the Jews adapted German linguistic material, laying the basis for a unique Judaized German, later known as Yiddish. Incorporated into Yiddish was a small, unique Romance component, unknown in the coterritorial German dialects; most of the Romance component was derived from Old French (specifically to a Judaized form of the latter), with a smaller corpus from Judeo-Italian. ${ }^{5}$ In this model, Yiddish is defined as a Judaized form of High German, and the Slavic component, which is extremely marked in all aspects of Yiddish, is regarded as a relatively late acquisition. In contemporary Eastern Yiddish dialects, the Slavic component reaches approximately $10 \%$ of the lexicon; a further $15 \%$ of the lexicon is of Hebrew-Aramaic origin - the two liturgical languages of the Jews - and the remainder German.

For reasons that cannot be repeated here for lack of space, I suggested (in 1991 and 1993) that a Germanic genetic assignment for Yiddish was unconvincing, since an analysis of the syntax and phonology of Yiddish strongly suggested that the latter was originally a Judaized form of Sorbian which became relexified to High German between the 9th and 12th centuries (on Judeo-Slavic in general, see my 1987). Despite the relexification to mainly High German vocabulary, the syntax, phonotactics and phonology of Yiddish have remained to this day West Slavic. However, due to the existence of its overwhelming High German lexicon, Yiddish has given the impression, to native speakers and non-observers alike, of being a form of High German.

My conception of Yiddish genesis differs from the traditional view in three important ways:

(a) I believe that Jews of Balkan origin, speaking South Slavic, Greek, and/or Balkan Romance, migrated into the (south)east German lands by the 9th century, at a time when these lands were still predominantly Sorbian-speaking. ${ }^{6}$

\footnotetext{
${ }^{5}$ The traditional view is best presented in Weinreich 1973 and Birnbaum 1979.

${ }^{6}$ Mieses deserves the credit for first suggesting that some Slavisms in Yiddish might be of Balkan origin (1924: 232-3, 271). This is a plausible suggestion, given the Balkan Romance substratum in Yiddish (see details in my 1992), but probably impossible to prove, since many Yiddish Slavisms could, in principle, be derived from any number of Slavic languages. Note that the Ashkenazic practice of baking braided bread for the Sabbath and other festive occasions appears to be of Greco-Roman origin; if so, it may have been acquired by Jews in the Balkans and brought north to the German lands. It survived in the new Ashkenazic homeland, since the custom was also practiced by Germans and West Slavs. Thus, the Yiddish name for the bread, xale < Biblical Hebrew hallāh 'piece of unbaked dough given to the priests as a tithe', looks like an attempt to
} 
(b) In the Germano-Sorbian lands, the Balkan Jews settled among Slavic speakers and became speakers of Sorbian. As the German Drang nach Osten gained momentum in the 9th century and Germans became the majority in the formerly Slavic territories, Sorbian (and Polabian) became replaced by German. In the case of most of the pagan Sorbs and Polabians, the shift to German was complete; that is, Sorbs and Polabians became bilingual in German, and then eventually gave up their original Slavic speech. Concomitantly, they also became Christians. The Sorbian Jews, on the other hand, were more resistant to German language, culture, and religion (Christianity), and thus made only a partial language shift, which involved a replacement of their lexicon, while the syntax and phonology remained largely intact. The tiny unique Romance and Greek component that remains in all dialects of Yiddish is most smoothly derived from north Italian, Friulan, and Balkan Romance dialects; a possible French contribution is evident only in a handful of Yiddish anthroponyms (see, e.g., Yiddish bunem 'male name' < French bon homme or Italian buon uomo literally 'good man'). ${ }^{7}$

(c) Ashkenazic ethnographic, linguistic and historical evidence all suggests that the bulk of the Balkan Jews who eventually migrated north into the mixed Germano-Sorb lands around the 9th century were not of ethnic Palestinian Jewish extraction. Rather, the European Jews consisted overwhelmingly of an indigenous proselyte community and a minority of Palestinian Jews. The demographic structure of the early European Jews accounts for the loss of spoken Hebrew and Aramaic in Europe very soon after Palestinian Jews arrived in Europe, and the absence of Hebrew and Aramaic literature (including the original texts of the Bible and Talmud) in Europe (and North Africa) until the 10th century. The evidence for widespread conversion to Judaism in the Hellenic world, the Balkans and Sorbian lands was laid out in Wexler 1991 and 1993.

There is good reason to believe that the Southern and Central Europeans who swelled the ranks of the Jewish community included a small Turkic population. The Slovene lands may have well been a part of the territory in which the conversions to Judaism took place, before the second millennium, when Christianity became institutionalized. One dramatic piece of evidence for the claim of a Turkic component comes from the mixed Avar-Jewish necropolis in Čelarevo (Vojvodina) that I mentioned above. Here, a number of Jewish graves were identified by Jewish decorations and an occasional Hebrew inscription on the stones.

The argument that some Avar invaders to Central and Southern Europe practiced Judaism (which they acquired in the mixed-Turkic Khazar lands - where Judaism became the state religion in the 8th century?) is further strengthened by the South Slavic and Rumanian tradition of associating Jews with legendary giants as well as by the West and South Slavic and Greek tradition of associating Avars with giants.

Judaize the pre-Christian German name of similar phonetic shape, which was derived from Holle, the name of the witch to whom the braided bread was traditionally dedicated (for details and rich bibliography, see my 1993: 115-8). Alternatively, the Ashkenazic Jewish braided bread might have been first acquired on German territory, since the practice of baking this sort of festive bread is well known among Germans (in rural areas especially). Where it exists today in West Slavic areas, the bread is called either by this or another Yiddish "Hebraism," e.g., barxes.

${ }^{7}$ On the unique Romance and Greek components in Yiddish, see Wexler 1992. 
The relevant data are as follows:

(a) 'giant' is formed from the term for 'Jew': North Bulgarian, Eastern Serbian žid, Bulgarian židovec, džidavec;

Rumanian jidov; ${ }^{8}$

(b) 'Jew' (substandard) is formed from the term for 'high, tall': Macedonian $v i$ sok 'Jew';'

(c) 'giant' is formed from the term for 'Avar':

Slovene ober ${ }^{10}$, Czech obr, Old Polish obrzym (Modern Polish olbrzym), Upper Sorbian hober, hobjer, Byzantine Greek óvrimos.

Some scholars have proposed that the term "Jew" became the basis for the term "mythical giant" since features such as abnormal tallness and a mythical prehistorical setting could be readily ascribed to an "alien" or non-indigenous element of the population." Given the fact that Jews and Avars were in contact (to judge from the important finds at the Avar necropolis at Celarevo and the tradition of deriving a Carniolan population from the Biblical "Ashkenazim" - see below), it may be that Jews and Avars were given the status of giants since there were adherents to Judaism among the Avar invaders of Central Europe and the Balkans in the 5 th-6th centuries. Hence, the specific association of giants with Jews could have

${ }^{8}$ Şaineănu noted that Rumanian used both Tătar 'Turk' and Jidov 'Jew' to denote giants, a fact which he ascribed to the conversion of the Khazar Turks to Judaism (1888: 154, 158, 160). In Siebenbürgen (Rumania) giants or Jews were allegedly the builders of fortresses, while in Bulgaria, Jews and Tatars performed this function (Winkler 1930-1: 1649). The Bulgarian and Rumanian data are discussed by the Bălgarski etimologičen rečnik I (1971): 543-4 and Matl 1956: 294, 306.

${ }^{9}$ For Macedonian, see Găbjuv 1900: 846. Jews and Avars are not alone in ascending to the status of giants; in Southern Bulgarian and Macedonian, giants are designated by the term elini literally 'Greeks' (see Matl 1956: 303, 306). A semantic development parallel to the Balkan example seems to characterize Ukrainian as well, if Ukrainian kozarljuha 'strong, courageous warrior' is derived from kozar 'Khazar' (see Pritsak 1963: 930); a pejorative development from the ethnic name Khazar is Hungarian kazár 'kike'. For further discussion, see Wexler 1987: 142. Another Slavic example of an ethnic term assuming the meaning of giant is Croatian, Russian ispolin, Polish stolin, stołym, stwolin etc. 'giant' from the name of an ethnic group known as Spalaei in Pliny (see Niederle 1924: 64, 82-3; Vasmer 1953-8; Machek 1956; Skok 1: 1971: 731).

${ }^{10} \mathrm{It}$ is interesting that Slovene is the only South Slavic language in this listing. See Vasmer 1953-8; Kollautz and Miyakawa 1970: 168, 171; Skok 2: 1972: 535; Wexler 1993: 196-7. Machek 1956, 1971 rejects the connection between 'giant' and 'Avar'. The Alans, ancestors of the Iranian Ossetes, have provided the Karaites (a Turkic-speaking Judaic sect in the Crimean Peninsula, western Belorussia, western Ukraine, and Lithuania) with their word for giant, alankasar (see Moskovich and Tukan 1985: 90). Note also that Romani biboldo 'Jew' (from the root for 'unbaptised') appears throughout German slang (Rotwelsch) in this meaning, but in Berlin speech, $b a$ bold $(e)$ is cited from 1812 in the meaning of 'big, strong man' (see Schildt and Schmidt 1986: 349 and Wolf 1956: 450). It would be interesting to know if the Gypsies acquired this new meaning of biboldo in the Balkans. Many Western European Gypsies are descended from groups which resided previously in the Balkans for several centuries.

${ }^{11}$ See Iliev 1890: 189-98, Mazon 1932, Bălgarski etimologičen rečnik I: 1971 373, 543-4, II: 1979: 89, Ivanov and Toporov 1980: 37, Pareba 1993, Lozanova 1994: 40 and Wexler 1993: 186-7. For the view that Jews were not intended by the Russian term Židovin, the name of a giant in the Russian byliny, see Mollova 1973: 101-2 and Vasil'ev 1995: 18-9. On the tendency to make non-existent peoples into giants, see Kollautz and Miyakawa 1970: 168, 171. 
been based on an actual historical event. It is inconceivable that Jews, lacking an army or autonomous political structure (apart from the Khazar Empire in the Ponto-Caspian steppe area, destroyed by the Kingdom of Rus' in the 10th century), could have been transformed into giants in the local folklore, had there been no connection between Jews and the warlike Avars. Most of the territories in which the term for Avar assumed the secondary meaning of giant were occupied by the Avars. ${ }^{12}$

Further support for the link between the Jews and Avars is that in the Austrian Steiermark there are several towns based on the ethnonym "Avar" located near a town called Judenburg (the name is attested since about 1080), see, e.g., Oberweg (1348 ff.) $<$ Common Slavic *obbrovit'i Old Church Slavic obrrinb 'Avar' (for this and other toponyms based on "Avar", see Mader 1986: 42, 67, 112). Even if Kronsteiner's alternative derivation of Judenburg from a Slavic root independent of Jews is correct (see his 1978: 153), the question still remains of why the placename eventually became reinterpreted as "town of the Jews"; due to a local tradition that associated Avars and Jews?

Curiously, one further term which combines the semantic primitives of "Jew" and 'large' is "Hebrew" golem 'supernatural male servant made out of clay whose purpose is to protect the Jews'. The term is traditionally derived from Hebrew 'amorphous substance' but I suspect that the Hebrew connection is the result of subsequent folk etymologizing. The real etymon is Slavic - either Old Czech hotomek (zemský) 'servant, judge's or executioner's helper', Old Polish holomek 'house servant' (first attested in the mid-15th century), or Czech holemy' 'strong' (< Common Slavic *golémı large'; see also dialectal Slovene golmeš 'very big'). The earliest Jewish account of the story of a golem-servant seems to be in the 13th-century Hebrew writings of German Jewish pietists and mystics, but since the story of a supernatural entity has non-Jewish Byzantine roots, we may want to posit a Balkan, Slavic or Greek origin for the Jewish story and "Hebrew" golsm. . $^{13}$

Particularly important and, to the best of my knowledge, ignored in the literature is Valvasor's mention of a local tradition that three Carniolan tribes, the Cimbri, Galatae and Teutones, were descended from the Ashkenazim (ibid., 1: 1689: 65, 2: 41-2, 45-9). This ethnonym is derived from the biblical Hebrew toponym ašk $n a z$, apparently located in Iranian speech territory, by which medieval European Jews first designated Slavs, then Germans, and finally Germans and German Jews. Valvasor rejects this claim as unfounded, as well as the claim that Hebrew aškənaz might be related to the Saxon dynastic name Askanien. ${ }^{14}$ The existence of such a tradition suggests that the Avar conquerors of the 5th-7th centuries may have included a significant number of Jews in their midst.

The tradition that Valvasor referred to finds some further support in the association of the Balkan Romance populations and the Ashkenazic Jews. Romancespeaking populations in the Balkans (Arumanians, Meglenorumanians, Rumanians)

\footnotetext{
${ }^{12}$ See Kronsteiner 1978: 143, fn 28. Old Russian participation in this isogloss probably has to be attributed to West Slavic influence.

${ }^{13}$ For details, see Skok 1934: 76, Zaręba 1965, Trubačev 1979, Rusek 1983 and my 1993: 132-3.

${ }^{14}$ Ibid., 2: 48-9. For a discussion of the Hebrew term aškanaz and the possible connection with Askanien, see my 1987: 160 and 1991: 48. Until recently I was unaware of Valvasor's discussion of these topics.
} 
are historically known by the epithet Vlax in Slavic languages. This ethnonym originally denoted a Celtic tribe, known in Latin as the Volcae (an ethnonym related to English Welsh, [Cornwall]. In older forms of German, Wälsche denoted both Celtic and Romance speakers (Andree 1874: 134). The term has become the basis of German Rotwelsch 'slang', literally 'beggar's incomprehensible (Romance!) language'. The Volcae were a partly Romanized Celtic tribe from the Middle Danube, some of whom migrated to Languedoc (between the Rhone and Toulouse). At least since the late Middle Ages, Germans, Slavs and Greeks have applied the term vlax to Romanized populations in their midst and sometimes even to other populations who adopted a pastoral or nomadic way of life, which was characteristic of the Romance minority. It is curious that the same root has become a common Ashkenazic Jewish (Yiddish) family name, in two forms, valax and blox (usually spelled Wallach and Bloch in Latin-alphabet languages, following German orthographic norms). The association between a Celtic tribal name in the Balkans (with Romance connections) and the Jews may be quite old. Note also that archaic Bulgarian dărmon 'leather grain sieve with large holes' surfaces in dialects with a variety of ethnic associations - Jews, Vlax and Roma (Gypsies), see, e.g., dărmon barba 'Jew', dărmonka 'Vlax woman', dărmule 'small Vlax' (the dialects where these forms are known are unspecified by the Bălgarski etimologičen rečnik I: 1971, which notes only that the Vlax were known to be specialists with sieves). It is unclear if this association of Jews and Vlax is in any way the basis for the Yiddish names cited above.

One final piece of evidence of Turko-Jewish contacts in the first millennium comes from the naming patterns of the Ashkenazic Jews themselves. While the practice of naming a child after the holiday on which it was born is found in many different cultures (see French Noël, Noëlle, Italian Pasquale - though nowadays the use of these names is no longer motivated by the fact of being born on the respective holidays), it seems to be particularly popular in Turkic speech communities. It is interesting to note that the use of the Hebrew terms pesah 'Passover' (the basis of Church Slavic pasxa) and hanūkkāh 'Hannukah' as boys' names are found historically among Jews only in the North European area and in the 10th-century Ukrainian Khazar community. Up until the 13th century, the European territory covered by these two names included the West and East Slavic territories and the eastern German lands, approximately up to the limes sorabicus which was the dividing line between the monolingual German lands of the Holy Roman Empire and the bilingual Germano-Slavic areas in the 9th century (see also Wexler 1987).

Documents from the late 14th century from the Slovene area preserve examples of both of these Hebrew names, see, e.g., Paskul a Jew from Triest resident in Maribor and Hankein (= Xanuka) also from Maribor (see Wenninger 1995a: 836-37). Either this naming tradition reached the Slovene lands with the arrival of Ashkenazic (Yiddish-speaking) Jews in the 13th century, or diffused to this area even earlier with the Judeo-Turkic migrations into the Balkans.

In addition to putative Turkic components in the Ashkenazic Jewish ethnogenesis, there is also a possibility of Iranian elements as well. Consider Yiddish šabaš 'tip given to the musicians at a wedding by guests who participate in the dancing' < Iranian $\check{s} \bar{a} b \bar{a} \breve{s}$ with the same meaning. The Iranianism surfaces in the slang registers of a number of West and East Slavic languages, Hungarian, Dutch and German in both a full and truncated form in the meaning of money (see details in Wexler 
1987: 64-69, 1993: 110). The practice of tipping musicians at a wedding is attested among the Polabian Slavs in western Germany (Polabian became extinct in the Luneburg region at the beginning of the 19th century), Macedonians (e.g., at Pešteni: see Leibman 1972: 128), as well as among western Hungarians (though in the latter community the tip is given to the church primate; see Rottleuthner 1985: 40). I do not know if either the term or practice was ever attested on Slovak, Croatian or Slovene territory. ${ }^{15}$

One final connection between Jews and Iranians involves the Balkan term for 'werewolf', e.g., Macedonian Greek vroukólakas, Cakonian Greek vourkólakas, Rumanian valcolác, Albanian vurvollák, Serbo-Croatian vukòdlak, Slovene volkodläk. The term (which Nichols believes comes ultimately from Iranian, and not from Slavic, as has been traditionally claimed) surfaces in early 13th-century German Hebrew texts (it is totally unknown in coterritorial German dialects, or in Yiddish itself, for that matter). This fact suggests that the German Jews were heirs to Balkan terms and traditions unknown among the coterritorial Germans; the best explanation is that these terms and traditions were brought to Germany by Balkan Jews (for details, see Vlachos 1971: 226, fn 48 and my 1993: 105-6). This may not be the only example of a linguistic or ethnographic Balkanism among German Jews. Another possible linguistic example might be the Yiddish expression fojglmilx literally 'bird's milk,' which has the meaning of something unusual, very precious, i.e., something unattainable or nonexistent. This expression is unattested in German dialects, but is widespread in the Slavic languages, as well as in Greek, Turkish, Arabic, and Modern Hebrew (where it is probably a loan from Yiddish); see Slovene ptičje mleko (now in this meaning or only as a botanical term, 'Ornithogalum'?), Bulgarian ptiče mljako. In South Slavic languages, or in East Slavic languages, due to the impact of Old Church Slavic, we can imagine a Greek source; Czech ptači mléko or Polish ptasie mleko on the other hand, are more problematic, given the absence of a significant Church Slavic imprint on West Slavic languages. It is not inconceivable that the Yiddish expression owes its origin to a Balkan Jewish language, and is the direct source of the expression in West Slavic languages.

Finally, there is evidence from the 15th century that Slovene Jewry either comprised a non-Yiddish-speaking minority, or developed on a non-Ashkenazic Jewish substratum. For example, in a German document from Kranj, dated 1446 and signed by five Jews, the 11th month of the Hebrew calendar, švatt, is transliterated as Sambat (Valvasor 4: 1689: 310, cited also by Friedenberg 1987: 297 without comment). Yiddish pronunciations of Hebrew retain Hebrew $\check{s}$ as such (except in the Belarusian and Lithuanian dialects of Yiddish which have sibilant confusion, and hence are irrelevant to the present discussion), e.g., Hebrew šabbāt > Yiddish šabes 'Sabbath, Saturday'; nor is there any justification for Hebrew $v$ becoming $m b$.

It appears that the name of the Hebrew month was confused (by Christian scribes?) with Balkan Slavic or Judeo-Greek reflexes of Hebrew šabbāt 'Saturday, sabbath'. In Judeo-Greek, geminated $b$ was dissimilated to $m b$ due to the absence of the former in the sound pattern; I assume only Jews would have been sensitive to the need to capture somehow the geminated consonant in the original Hebrew.

15 On Iranian populations in the East Balkans in the early Christian era, see Du Nay 1977: 189-90, 201-2. 
Compare Judeo-Greek sambata vs. standard Greek sabbata, sabbaton 'Saturday, Sabbath', with distinctly "non-Hebraic" forms. The Judeo-Greek reflex has a limited diffusion in neighboring Macedonian dialects, see Southeast Macedonian sambuta (northeast of Saloniki) Southwest (Kostur, Korça) Macedonian səmba vs. standard Macedonian sabota (see Vidoeski 1983: 130, 132 and further discussion in Wexler 1987: 24-27). There is no $m$ in the Slovene ${ }^{16}$ Serbo-Croatian or Bulgarian cognates, however, though neighboring non-Slavic languages do follow the Judeo-Greek pronunciation norm, see, e.g., Hungarian szombat, Rumanian sâmbătă. The replacement of $\breve{s}$ by $s$ could have also developed in a (Judeo-)Greek-speaking milieu. Note also that in the western-most Iranian language, Ossete, Hebrew šabbāt surfaces as sabat 'Saturday, sabbath'. Ossete has a few Hebrew, Aramaic, and Judeo-Greek elements. ${ }^{17}$

The example of Sambat from the Slovene texts suggests that a South Balkan pronunciation norm of Hebrew may have been diffused to the northern-most Balkans. This is valuable evidence in support of the thesis that the Ashkenazic Jews are descended in the main from migrants from the Balkans.

I believe that the evidence both presented here and referred to in other studies justifies a fresh look at Jewish migrational patterns to and within early medieval Europe. My findings suggest that the Ashkenazic Jews are in large part descended from a Slavo-Turkic proselyte population rather than from transplanted Palestinian Jews. Slavo-Turks may have become Judaized in the ethnically mixed Khazar lands (in the Ponto-Caspian steppes) and/or in the Slavo-Avar settlements in the Balkans. If the former, then the first Jews in the Balkans were very likely of Asian Turkic rather than Mediterranean Jewish origin, and were part of the Drang nach Westen of Slavs, Avars, Magyars, and others, which was gathering momentum beginning with the 6th century. If the latter, then the first Jews in the Balkans were to some extent of indigenous extraction. In any case, the German Jews could not be the descendants of French and Italian Jews, as is commonly believed. Once ensconced in the German lands in the early second millennium, some of the Jews subsequently migrated south into northern France where they assisted in the formation of major Jewish cultural centers, though most German Jews joined the Germans in the latter's Drang nach Osten into monolingual Slavic territories, where they were to coexist until World War II. The Slovene lands were probably part and parcel of the broader Balkan context in which Ashkenazic Jewry - the largest branch of the so-called diaspora Jews - was created. ${ }^{18}$

${ }^{16}$ [The Slovene evidence is as yet ambiguous. Common Slavic $*_{O} O$ and $*_{Q}$ have merged in Slovene, rendering the recovery of the form at the time of borrowing problematic. Upper Carniolan zbóta $(<*$ subota $<*$ sobota $(?))$ as well as Inner Carniolan sabûota point to the possibility of $*_{o}$; on the other hand, the place name Murska Sobota is attested as Murazombata (1348), Murazumbata (1365), and Mura Schombath (1423), indicating a nasal element (see Bezlaj 1995: 282). - Op. ed.]

${ }^{17}$ See Wexler 1987: 21, 222, 226-27. On Ossete, see also footnote 10 above.

${ }^{18}$ Future research should explore why Slovene lacks Jewish expressions that surface in neighboring languages among Christians, e.g., the Judeo-Greek practice of denoting the holiday of Yom Kippur (Day of Atonement) as the "great day" surfaces in Hungarian as hosszúnap and in Czech as dlouhy den; there is apparently no trace of this term in Slovene. Slovene also has no reflex of Judeo-Greek $m$ in the word for Saturday. 


\section{References}

Andree, R. (1874). Wendische Wanderstudie. Zur Kunde der Lausitz und der Sorbenwenden. Stuttgart.

Bălgarski etimologičen rečnik (1971-95). Vols. I-IV. Sofija.

Bezlaj (1995). F. Bezlaj Etimološki slovar slovenskega jezika III. Ljubljana.

Birnbaum, S. A. (1979). Yiddish. A survey and a grammar. Toronto - Buffalo.

Bunardžić, R. (1980). Izložba menore iz Čelareva. Beograd.

Detoni, M. (1957-8). Mariborski geto. Jevrejski almanah 72-4.

Du Nay, A. (1977). The early history of the Rumanian language. Lake Bluff, Illinois.

Friedenberg, D. (1987). Medieval Jewish seals from Europe. Detroit.

Găbjuv, P. K. (1900). Prinos kăm bălgarskite tajni ezici. Sbornik za narodni umotvorenija, nauka i knižnina 16-17: 842-75.

Iliev, At. (1890). Bălgarskite predanija za ispolini, narečeni elini, židove i latini. Sbornik za narodni umotvorenija i narodopis 3: 179-205.

Ivanov, V. V. and V. N. Toporov (1980). O drevnix slavjanskix ètnonimax. (Osnovnye problemy i perspektivy.) Slavjanskie drevnosti. Ėtnogenez, materialnaja kultura drevnej Rusi, 11-45. Kiev.

Kollautz, A. and H. Miyakawa (1970). Geschichte und Kultur eines völkerwanderungszeitlichen Nomadenvolkes. Die Jou-Jan der Mongolei und die Awaren in Mitteleuropa 2. Die Kultur. Klagenfurt-Bonn.

Kronsteiner, O. (1978). Gab es unter den Alpenslawen eine kroatische ethnische Gruppe? Wiener slavistisches Jahrbuch 24: 137-57.

Lazarus, F. (1968). Marburg. Germania judaica, ed. Z. Avneri, 2/2: 522-3. Tübingen.

Leibman, R. (1972). Wedding customs in the Ohrid village of Pešteni. Makedonski folklor 9-10: 125-40.

Lozanova, G. (1994). The category of "alien-one's own" in folk culture. Études balkaniques 30: 37-42.

Lunski, X. (1924). Iserlins jidiš. Jidiše filologje 288-97. Warsaw.

Machek, V. (1956). Expressive Vokaldehnung in einigen slavischen Nomina. Zeitschrift für Slawistik 1 (4): 33-40.

- - (1971). Etymologický slovník jazyka českého. Prague.

Mader, R. (1986). Die Alpenslawen in der Steiermark. Eine toponomastisch-archäologische Untersuchung. Vienna.

Mat1, J. (1956). Zur Bezeichnung und Wertung fremder Völker bei den Slaven. Festschrift für Max Vasmer zum 70. Geburtstag, eds. M. Woltner and H. Bräuer, 293-306. Wiesbaden.

Mazon, A. (1932). Svjatogor ou Saint-Mont le géant. Revue des études slaves 12: $160-201$.

Mieses, M. (1924). Die jiddische Sprache. Berlin - Vienna.

Mollova, M. (1973). Quelques lexèmes turks septentrionaux en $\check{g}-\check{c}-j \ldots$ dans les langues slaves méridionales. Zeitschrift für Balkanologie 9 (1-2): 89-127. 
Moskovich, W. and B. Tukan (1985). Caraimica. The problems of the origin and history of East European Khazars in the light of linguistic evidence. Slavica hierosolymitana 7: 87-106.

Nedomački, V. (1988a). Arheološki nalazi. Židovi na tlu Jugoslavije, 17-25. Zagreb.

- - (1988b). Geta i mahale. Ibid. 27-31.

- - and S. Goldstein (1988). Jevrejske općine u jugoslavenskim zemljama. Ibid. $113-41$.

Nichols, J. (1987). Russian vurdalak 'werewolf' and its cognates. Language, literature, linguistics. In honor of Francis J. Whitfield on his seventieth birthday, March 25, 1986, eds. M. S. Flier and S. Karlinsky, 165-77. Berkeley.

Niederle, L. (1924). Slovanské starožitnosti. Původ a počátky Slovanů východních 1 (4). Prague.

Pareba, M. (1993). Otraženie staryx ètničeskix i jazykovyx kontaktov na Balkanax v bolgarskix i serboxorvatskix dialektnyx nazvanijax nekreščennogo rebenka. Balkanskoe ezikoznanie 36: 275-80.

Pritsak, O. (1963). Altaic elements. Ukraine. A concise encyclopaedia, ed. V. Kubijovyč, 1: 928-31. Toronto.

Rottleuthner, W. (1985). Bäuerliches Hochzeitsbrauchtum in Südmähren zur Jahrhundertwende (Prittlach 1895). Österreichische Zeitschrift für Volkskunde n. S. 39: $25-44$.

Rusek, J. (1983). Bulgarskie golěm’ 'wielki, magnus'. Rocznik stawistyczny 43: 21-28.

Şaineănu L. (1888). Jidovi său Tătari său uraisii. Anuar pentru Israeliți 11: 153-60.

Schildt, J. and H. Schmidt (eds.) (1986). Berlinisch. Geschichtliche Einfuhrüng in die Sprache einer Stadt. Berlin.

Skok, P. (1934). Dolazak Slovena na Mediteran. Split.

- - (1971-4). Etimologijski rječnik hrvatskoga ili srpskoga jezika 1-4. Zagreb.

Trubačev, O. N. (ed.) (1979). Ėtimologičeskij slovar' slavjanskix jazykov. Praslavjanskij leksičeskij fond 6. Moskva.

Tykocinski, H. (1934). Laibach. Germania judaica, eds. I. Elbogen, A. Freimann, H. Tykocinski, 1: 152. Breslau; reprinted Tübingen 1963.

Valvasor, J. W. (1689). Die Ehre des Hertzogthums Crain und historisch-topographische Beschreibung 1-4. Translated into German by E. Francisci. Ljubljana.

Vasil’ev, M. A. (1995). «Xors židovin» i drevnerusskoe jazyčeskoe božestvo v kontekste problem Khazaro-slavica. Slavjanovedenie no. 2: 12: 21.

Vasmer, M. (1953-8). Russisches etymologisches Wörterbuch 1-3. Heidelberg.

Vidoeski, B. (1983). A survey of the Macedonian dialects. In B. Koneski, A historical phonology of the Macedonian language, 117-34. Heidelberg.

Vlachos, T. (1971). Geister- und Dämonenvorstellungen im südosteuropäischen Raum griechischer Sprachzugehörigkeit. Österreichische Zeitschrift für Volkskunde. n. S. 25: 217-48. 
Weinreich, M. (1924). Onmerkungen [Notes to Lunski 1924]. Jidiše filologje, 297-302. Warsaw.

- - (1973). Gešixte fun der jidišer sprax 1-4. New York.

Wenninger, M. (1987a). Cilli. Germania judaica, ed. A. Maimon, 3/1: 206-10. Tübingen.

- - (1987b). Judenburg. Ibid.: 592-6.

- - (1987c). Laibach. Ibid.: 698-702.

- - (1995a). Marburg. Germania judaica, eds. A. Maimon, M. Breuer and Y. Guggenheim, 3(2): 832-46. Tübingen.

- - (1995b). Radkersburg. Ibid.: 1163-8.

- - (1995c). St. Veit an der Glan. Ibid.: 1303-4

Wexler, P. (1987). Explorations in Judeo-Slavic linguistics. Leiden.

- - (1991). Yiddish - the fifteenth Slavic language. International Journal of the sociology of language 91: 1-150, 215-25.

- - (1992). The Balkan substratum of Yiddish. (A reassessment of the unique Romance and Greek components). Wiesbaden.

- - (1993). The Ashkenazic Jews. A Slavo-Turkic people in search of a Jewish identity. Columbus, Ohio.

Winkler (1930-1). Heiden. Handwörterbuch des deutschen Aberglaubens, eds. E. Hoffmann-Krayer and H. Bächtold-Stäubli, 3, columns 1634-53. Berlin Leipzig.

Wolf, S. A. (1956). Wörterbuch des Rotwelschen. Mannheim.

Zaręba, A. (1965). Z zapomnianych wyrazów polskich: (z)golemy. Prace filologiczne 18 (4): 199-206.

Prispelo januarja 1996, sprejeto decembra 1996

Received January 1996, accepted December 1996

Zakaj je možno, da so obstajali stiki med Slovenci in Židi pred 1. 1000 n. š.

Običajno se domneva, da so se Židje do konca prvega tisočletja selili iz Sredozemlja prek severne Francije in Italije na Bavarsko in v Porenje. Judaizirana nemška narečja (znana kot jidiš) naj bi se oblikovala, ko so ti romansko govoreči Židje prevzeli nemška narečja. Tako se jidiš običajno pojmuje kot judaizirana oblika visokonemških narečij. V prispevku je pokazano, kako jezikoslovni dokazi omogočajo vzpostavitev nove teorije o selitvi Židov (tako palestinskih emigrantov kot domorodnih evropskih spreobrnjencev), namreč da so se do poznega prvega tisočletja n. š. prek Balkana selili na dvojezična lužiškosrbsko govoreča ozemlja. S tega stališča bi morali jidiš oblikovati balkanski židovski emigranti, ki so govorili enega ali več balkanskih jezikov: romansko, grško in/ali južnoslovansko. V nasprotju z običajnim pojmovanjem je na jidiš najbolje gledati kot na narečje lužiščine, ki je bilo naposled preleksikalizirano $\mathrm{s}$ srednjevisokonemškim besedjem (kar je na koncu imelo za posledico slovanski jezik $\mathrm{s}$ prevladujočim nemškim besediščem). Prispevek poudarja dokaze, ki izhajajo s slovenskega ozemlja. 
Why There May Have Been Contacts between Slovenes and Jews before 1000 A.D.

The traditional view of Jewish settlement history in Europe posits migrations from the Mediterranean region through northern France and Italy into Bavaria and the Rhineland by the end of the first millennium. The Judaized dialects of German (known as Yiddish) were allegedly created when these Romance-speaking Jews switched to regional German dialects. Yiddish has traditionally been defined as a Judaized form of High German dialects. This paper will demonstrate how linguistic evidence allows us to postulate an innovative theory about the migration of Jews (both Palestinian emigres and indigenous European converts) - namely, through the Balkans into the bilingual Sorbo-German lands by the late first millennium A.D. In this view, Yiddish was created by Balkan Jewish emigres speaking one or more Balkan languages: Romance, Greek and/or South Slavic. Contrary to the common view, Yiddish is best seen as a dialect of Sorbian which eventually became relexified to Middle High German (thus resulting in a Slavic language with an overwhelming German vocabulary). The article specifically emphasizes evidence from the Slovene territory. 